\title{
Tree mortality in the dynamics and management of uneven-aged Norway spruce stands in southern Finland
}

\author{
Sauli Valkonen $^{1}$ (D) Lucie Aulus Giacosa ${ }^{2}$ D . Juha Heikkinen ${ }^{1} \mathbb{D}$
}

Received: 19 March 2020 / Revised: 2 June 2020 / Accepted: 17 June 2020 / Published online: 30 June 2020

(c) The Author(s) 2020

\begin{abstract}
This study focused on tree mortality in spruce-dominated stands managed using the single-tree selection method in southern Finland. Together with regeneration and tree growth, mortality is one of the basic elements of the stand structure and dynamics in selection stands. The study was based on data acquired from a set of 20 permanent experimental plots monitored with repeated measurements for 20 years. The average mortality in the number of stems $(N)$ was 4.45 trees ha ${ }^{-1} \mathrm{a}^{-1}$, in basal area $(G) 0.07 \mathrm{~m}^{2} \mathrm{ha}^{-1} \mathrm{a}^{-1}$, and in stemwood volume $(V) 0.56 \mathrm{~m}^{3} \mathrm{ha}^{-1} \mathrm{a}^{-1}$. In relative terms it was $0.50 \%$ of $N, 0.30 \%$ of $G$ and $0.27 \%$ of $V$, respectively. Wind and snow were the most common causes of mortality, while deaths by biotic causes (mammals, insects, pathogens) were extremely rare. Some 6-10\% of the total loss in the number of stems and volume was attributable to the loss or removal of trees that sustained serious damage in harvesting. Most of the mortality occurred in the smallest diameter classes of up to $20 \mathrm{~cm}$. Such a high mortality among small trees can have an adverse influence on the sustainability of selection structures if not successfully checked in harvesting and management.
\end{abstract}

Keywords Stand dynamics · Picea abies $\cdot$ Mortality $\cdot$ Silviculture $\cdot$ Stand structure $\cdot$ Uneven-aged management

\section{Introduction}

Tree mortality is one of the main dynamic components controlling the development and productivity of tree stands managed with the single-tree selection system, along with tree growth, regeneration, and harvesting. The relationships between the basic elements of growth and yield with special emphasis on selection management are presented in Lundqvist (2004). Mortality is important in making the gross yield into net yield in terms of merchantable timber since dead trees are not suitable for industrial purposes. Mortality among seedlings and saplings has been addressed in many studies in the Nordic area (see review by Lundqvist 2017)

Communicated by Thomas Knoke.

Sauli Valkonen

Sauli.Valkonen@luke.fi

1 Natural Resources Institute Finland (Luke), P. O. Box 2, 00791 Helsinki, Finland

2 UMR 1224 ECOBIOP, INRAE, UNIV PAU et PAYS ADOUR, E2S Energy Environment Solutions, Aquapôle Quartier Ibarron n¹73, RD 918 - Route de St Jean de Luz, 64310 Saint-Pée-sur-Nivelle, France but mortality of the larger trees constituting the main crop is less studied. Experimental results on growth and structural dynamics in uneven-aged stands have mostly been presented in net values, assuming that the role of mortality is generally small. Lundqvist (1993) presented stand-level mortality rates in a set of permanent field trials managed using single-tree selection and carried out observations for many decades with repeated measurements in Sweden. Lundqvist et al. (2007) reported mortality rates in two experimental stands including thinning from above as a treatment with relevance to selection harvesting. However, harvesting damage in singletree selection is well covered by several studies (Fjeld and Granhus 1998; Granhus and Fjeld 2001; Surakka et al. 2011; Sirén et al. 2015) and practical experience.

Continuous cover forestry (CCF) and selection management are still rarities in the Nordic area but are gaining attention among decision makers and forest managers as an alternative that could mitigate problems related to biodiversity and ecosystem services, economics, and climate change. Possible differences in wood yields and productivity are one of the key areas of deliberation and the role of mortality among the main crop trees is an integral component. According to Nevalainen (2017), factors behind possible differences between management strategies include tree species 
diversity, age structure, understory structure, tree density, rotation length, thinning intensity and silvicultural operations. Uneven-aged stands are thought to be quite resistant and resilient to disease and damage (O'Hara and Ramage 2013). Nevalainen (2017) concluded that damage risks are generally lower in uneven-aged management regimes than in even-aged regimes. of 16 major risk factors assessed for spruce stands, the risk in uneven-aged management was lower for 11 factors (frost, nutrient imbalance, wind, European spruce bark beetle, large pine weevil, brush, weed, bank vole, short-tailed vole, moose, honey mushrooms), equal for 5 factors (snow, 6-toothed spruce bark beetle, harvesting, root rot), and greater in none of them.

Only a couple of empirical comparisons of damage risks in even- and uneven-aged management schemes exist in the Nordic area, addressing fungal and insect damage (Björkman et al. 2011; Klapwijk et al. 2016) and windthrow (Pukkala et al. 2016). None of these, or other works, have yet attempted to produce tangible estimates on the rate and significance of mortality in even-aged and uneven-aged management strategies. In studies comparing even-aged and uneven-aged management strategies with modeling, simulation and optimization, net growth has been the focus with no explicit attention to mortality (Eid and Tuhus 2001; Gobakken et al. 2008; Pukkala et al. 2009, 2013; Buongiorno et al. 2012; Rämö and Tahvonen 2014, 2015, 2017; Tahvonen et al. 2010, Tahvonen and Rämö 2016; Shanin et al. 2016; Sinha et al. 2017).

In the European context, very little empirical research on tree mortality in uneven-aged stands with a major position of Norway spruce is available. In the classic Plenterwald system, mortality has not been emphasized as such, because it is generally prevented by the promotion of tree vitality and stability (Mayer 1999; Schütz 2001). Research on mortality has mostly been linked to the construction of models for simulation (see Hülsman (2016) for a comprehensive review). Recently mortality has gained more attention in association with climate change, storms, and resilience, especially in modeling and simulation (e.g., Cordonnier et al. 2008; Bircher 2015; Hilmers et al. 2020).

This study focused on mortality based on a set of permanent experimental plots under single-tree selection in spruce stands that have been used in studies on volume growth (Shanin et al. 2016; Hynynen et al. 2019), and studies on regeneration and the development of seedlings and saplings (Saksa 2004; Saksa and Valkonen 2011; Eerikäinen et al. 2014). The data acquired from the plots is suited for analyses of mortality from stand to individual tree level, because the full range of tree diameter classes has been covered with repeated measurements for several five-year periods.

The purpose of this study was to assess the role of tree mortality as a dynamic component of stand structure and productivity in spruce-dominated stands managed using the single-tree selection method based on long-term monitoring in the ERIKA experimental set. The scale of mortality in terms of the number of stems $(N)$, basal area $(G)$ and stemwood volume $(V)$, both in absolute and relative terms, was the basic yield attribute that the focused on. Greater stand density was hypothesized to induce higher mortality. Mortality rates reported for even-aged stands under comparable conditions and those applied in major simulation models in the Nordic area were juxtaposed with our results.

\section{Materials and methods}

The study material was acquired from a set of 20 experimental plots in southern Finland $\left(60^{\circ} 35^{\prime} \mathrm{N}-62^{\circ} 40^{\prime}, 25^{\circ} 00^{\prime}-27^{\circ}\right.$ $10^{\prime}$ E) at five locations, namely Vesijako-Kailankulma (VES), Lapinjärvi (LAP), Evo (EVO), Vesijako-Puolivälinmäki (VEP) and Suonenjoki (SUO). The plots had been explicitly established for studies on tree and stand development in managed, uneven-aged Norway spruce forests under the 'ERIKA' research project at the Finnish Forest Research Institute (METLA), later Natural Resources Institute Finland (Luke). The plots had been established in 1991-1992 at all locations except Suonenjoki where they were established in 1996. The study sites were subjectively selected from some 40 candidate stands available for the project on properties owned by METLA, Metsähallitus (administrator of stateowned forests in Finland), Evo School Forest, and a few other owners. Stands that displayed a great degree of resemblance to a classic single-tree selection structure in terms of diameter distribution and homogenous spatial distribution were a priori assessed to have a potential to develop toward a sustainable selection structure. At the end of the observation period in 2011, 14 stands represented a full-storied "Plenterwald" structure and 6 were multi-layered as defined by Ahlström and Lundqvist (2015).

The stands had been treated by conducting selection cuttings of an unknown intensity and at undetermined intervals during 1950-1980. In 1984-1988, however, they were all treated under a single-tree selection policy with a variable intensity. In 1996, a selection cutting was carried out to enhance uneven-aged structures in 15 stands and to reset their basal areas to the original values of 1984-1988. The emphasis of the removal were the larger diameter classes $(d>30 \mathrm{~cm})$. However, some larger trees had to be retained in many stands in order to achieve the target basal area. On the other hand, a number of mid-sized trees $(20 \mathrm{~cm}<d<30 \mathrm{~cm})$ were removed where there was a major surplus. The average basal area removal was $5.9 \mathrm{~m}^{2} \mathrm{ha}^{-1}(24.6 \%$, see Table 1$)$. Five stands were not harvested due to their operationally unjustifiable harvestable volumes. In three of them (VES $13,14,16)$, only three years had passed since the previous cutting treatment, and on two of them (LAP 1, EVO 3) the 
Table 1 Stand characteristics at the beginning in (1991) and at the end of the monitoring period in (2011), and basal area removal in 1996

\begin{tabular}{|c|c|c|c|c|c|c|c|c|c|c|c|}
\hline \multirow[t]{2}{*}{ Area } & \multirow[t]{2}{*}{ Stand } & \multirow[t]{2}{*}{ Site type } & \multicolumn{2}{|l|}{$N\left(\mathrm{ha}^{-1}\right)$} & \multicolumn{2}{|l|}{$G\left(\mathrm{~m}^{2} \mathrm{ha}^{-1)}\right.$} & \multirow[t]{2}{*}{$G_{\text {rem }(\%)}$} & \multicolumn{2}{|l|}{$V\left(\mathrm{~m}^{3} \mathrm{ha}^{-1)}\right.$} & \multicolumn{2}{|c|}{ Admixture (\%) } \\
\hline & & & Beginning & End & Beginning & End & & Beginning & End & Beginning & End \\
\hline \multirow[t]{7}{*}{ VES } & 1 & MT & 1250 & 1244 & 22.3 & 28.3 & 25 & 181 & 274 & 24 & 14 \\
\hline & 2 & MT & 1206 & 1250 & 19.9 & 26.6 & 31 & 163 & 254 & 32 & 15 \\
\hline & 5 & MT & 706 & 1013 & 16.7 & 25.3 & 27 & 164 & 266 & 0 & 0 \\
\hline & 7 & MT & 800 & 813 & 16.9 & 22.5 & 23 & 148 & 231 & 25 & 15 \\
\hline & 13 & MT & 569 & 600 & 12.4 & 22.8 & - & 98 & 243 & 19 & 13 \\
\hline & 14 & OMT & 400 & 456 & 15.7 & 29.4 & - & 168 & 363 & 0 & 0 \\
\hline & 16 & MT & 706 & 900 & 15.6 & 25.9 & - & 136 & 273 & 38 & 27 \\
\hline \multirow[t]{4}{*}{ LAP } & 1 & OMT & 1188 & 1431 & 14.2 & 27.7 & - & 118 & 261 & 50 & 52 \\
\hline & 5 & OMT & 1181 & 900 & 34.9 & 34.5 & 30 & 371 & 389 & 72 & 76 \\
\hline & 7 & OMT & 619 & 1250 & 19.2 & 28.3 & 15 & 189 & 270 & 62 & 53 \\
\hline & 13 & MT & 650 & 931 & 18.7 & 22.2 & 26 & 188 & 218 & 47 & 39 \\
\hline \multirow[t]{3}{*}{ EVO } & 2 & MT & 500 & 394 & 17.4 & 14.2 & 21 & 172 & 145 & 29 & 37 \\
\hline & 3 & MT & 331 & 481 & 9.9 & 15.8 & 0 & 91 & 160 & 0 & 0 \\
\hline & 4 & MT & 1081 & 988 & 22.4 & 26.0 & 21 & 208 & 278 & 45 & 25 \\
\hline \multirow[t]{2}{*}{ VEP } & 2 & MT & 488 & 444 & 18.3 & 23.2 & 24 & 179 & 255 & 0 & 0 \\
\hline & 4 & MT & 863 & 963 & 19.8 & 24.8 & 27 & 187 & 254 & 13 & 3 \\
\hline \multirow[t]{4}{*}{ SUO } & 1 & MT & 1038 & 913 & 19.2 & 22.1 & 14 & 150 & 197 & 9 & 7 \\
\hline & 2 & MT & 675 & 469 & 27.4 & 22.1 & 28 & 272 & 230 & 29 & 23 \\
\hline & 3 & MT & 875 & 638 & 26.6 & 22.2 & 29 & 233 & 217 & 23 & 24 \\
\hline & 6 & MT & 1206 & 863 & 25.9 & 23.5 & 29 & 216 & 217 & 16 & 20 \\
\hline
\end{tabular}

For stands at SUO the monitoring period began in 1996

OMT Oxalis-Myrtillus type and MT Myrtillus type according to Cajander (1926), $N=$ number of stems for trees with $d \geq 5 \mathrm{~cm}$, ha ${ }^{-1} ; G=$ stand $^{3}$ basal area $\mathrm{m}^{2} \mathrm{ha}^{-1} ; G_{\text {rem }}=$ basal area removal in 1996,\%;V=stem volume, $\mathrm{m}^{3} \mathrm{ha}^{-1}$; Admixture=proportion of stem volume obtained for species other than spruce, $\%$

operationally justifiable harvestable volume of $40 \mathrm{~m}^{3} \mathrm{ha}^{-1}$ had not been attained due to slow growth over the 8 years since the previous selection cutting. Advance tree and strip road marking, manual felling, debranching and cut-tolength culling with chainsaw, and forwarder transportation were employed during the harvesting. The trees to fell were selected and very well marked in advance, and other trees removed or lost in harvesting were considered harvest loss.

The forest stands represented the most common spruce sites on mineral soil, i.e., mesic Oxalis-Myrtillus type (OMT) and submesic Myrtillus type (MT) (Cajander 1926; see Table 1). The major part of the total stand volume was composed of spruce (on average, $68 \%$ at the beginning and $77 \%$ the end of the study period, respectively). The remaining portion of the stand volume comprised of Scots pine (Pinus sylvestris L.) and various broadleaf species, mainly silver birch (Betula pendula Roth), downy birch (Betula pubescens Ehrh.) and aspen (Populus tremula L.).

The trees were measured with identical protocols at 5 -year intervals in 1991, 1996, 2001, 2006, and 2011. In each stand, all measurements took place on a $40 \mathrm{~m} \times 40 \mathrm{~m}$ plot. All trees taller than or equal to $0.1 \mathrm{~m}$ were described according to their species and their coordinates, and measured for height ( $h$, in $\mathrm{cm}$ with $h<1.3 \mathrm{~m}$, otherwise in $\mathrm{dm})$. The diameter at breast height $(d, \mathrm{~mm})$ was measured for all trees with $h>1.3 \mathrm{~m}$. The measurements were repeated in 1991, 1996, 2001, 2006, and 2011. This study was based on a subset of data containing the observations of trees with $d \geq 5.0 \mathrm{~cm}$ at any measurement.

In the data preparation, each tree was individually traced throughout its existence during the 20-year observation period. A death was recorded if a tree was alive at the beginning of the 5-year period, but dead (standing or downed) or missing at the end of it. If possible, the cause of death was ascribed to: wind, snow, another climatic or edaphic cause, tree or plant interaction (e.g., shading, competition or abrasion), harvesting, other human-induced cause, mammal (except human), insect, fungi, other, or unknown causes. In about half of the cases a cause of death was recorded, when it was assuredly or very confidently identified. For the other half, the cause of death was unidentified. It was very hard to determine whether a small downed tree had fallen during harvesting in 1996 or died of natural causes during the next 5 years prior to the detection of its death. Trees assigned to harvest loss were kept in the data along with the rest assigned to natural causes. The tree diameter and height 
were usually represented by the measurement at the end of the 5 -year period if available, but the values at the beginning were used if the tree had disappeared or if the end value could not be acquired. The tree volume was calculated from the diameter and height using the stem volume equations by Laasasenaho (1982).

The influence of stand density (stem number, basal area, and volume) on mortality was analyzed using a mixed model extension of beta regression models (Ferrari and CribariNeto 2004) with region- and stand-specific random components. Beta regression is similar to using generalized linear models, and it allows a logistic curve to fit to the data where the response variable is a proportion, which iscontinuous and restricted to the interval from 0 to 1 . Accordingly, the response variable $Y$ formed the relative mortality model. This involved the number of stems $(N)$, basal area $(G)$, or stemwood volume $(V)$ lost during a five-year period divided by the corresponding stock in the beginning of the period. The relative mortality $Y_{i j t}$ in the $j$ th stand of the $i$ th region during the $t$ th period was assumed to be a realization from the beta distribution with the mean $\mu_{i j t}$ such that

$g\left(\mu_{i j t}\right)=a+b X_{i j t}+w_{i}+z_{i j}$

where $g$ is the logistic link function

$g(\mu)=\log [\mu /(1-\mu)]$,

$X_{i j t}$ is the stand density at the beginning of the period, $w_{i}$ and $z_{i j}$ are the random components for the $i$ th region and its $j$ th stand, and $a$ and $b$ are unknown model parameters to be estimated from the observed data. Random effects $w_{i}$ and $z_{i j}$, were assumed to be mutually independent and normally distributed with a zero mean and constant variances $\sigma_{w}^{2}$ and $\sigma_{z}^{2}$, Following Ferrari and Cribari-Neto (2004), we assumed that the variance of $\mathrm{Y}$ was related to its mean through the equation

$\operatorname{var}\left(Y_{i j t}\right)=\frac{\mu_{i j t}\left(1-\mu_{i j t}\right)}{1+\phi}$,

where $\phi>0$ is a constant precision parameter to be estimated from the data, along with the variances $\sigma_{w}^{2}$ and $\sigma_{z}^{2}$ of the random components. The models were fitted in the $\mathrm{R}$ environment ( $\mathrm{R}$ Core Team 2019) using the glmmTMB package (Brooks et al. 2017).

\section{Results}

\section{Overall mortality}

The average mortality in the stands was $N$ (number of stems $)=4.45$ trees $\mathrm{ha}^{-1} \mathrm{a}^{-1}, G$ (basal area) $=0.068 \mathrm{~m}^{2}$ $\mathrm{ha}^{-1} \mathrm{a}^{-1}, V$ (stemwood volume $)=0.56 \mathrm{~m}^{3} \mathrm{ha}^{-1} \mathrm{a}^{-1}$. In relative terms, the mortality was $0.50 \%$ of $N, 0.30 \%$ of $G$ and $0.27 \%$ of $V$, where the reference value of $N, G$, or $V$ was the average for the respective 5-year period.

The mortality was higher during the last two 5-year periods than during the two previous ones (Fig. 1). However, two incidents with exceptionally high mortality occurred during the latter part of the period. There was storm damage at the SUO location in 2001-2006 and a European spruce bark beetle (Ips typographus L) outbreak in 2006-2011 at the LAP location (referred to as Ips damage later in the text). Without these incidents the temporal increase would have been much less ostensible.

The mortality rates were much lower when the two fiveyear observation periods containing the incidents were excluded from the data, especially in terms of the basal area and volume. The respective average annual mortality rates were $N=2.94$ trees ha- $\mathrm{ha}^{-1}, G=0.030 \mathrm{~m}^{2} \mathrm{ha}^{-1} \mathrm{a}^{-1}$, $V=0.21 \mathrm{~m}^{3} \mathrm{ha}^{-1} \mathrm{a}^{-1}$ and in relative terms $0.40 \%$ of $N$, $0.17 \%$ of $G$ and $0.13 \%$ of $V$.

\section{Influence of stand density}

The mortality was seemingly higher with a greater stand density in straightforward plotting of the data (Fig. 2). However, none of the analyzed relationships between density $(N, G, V)$ and the relative mortality variables were significant (Table 2A). The relationships were even less close with the removal of the two five-year periods containing the exceptionally high wind and Ips damage incidents (Table 2B).

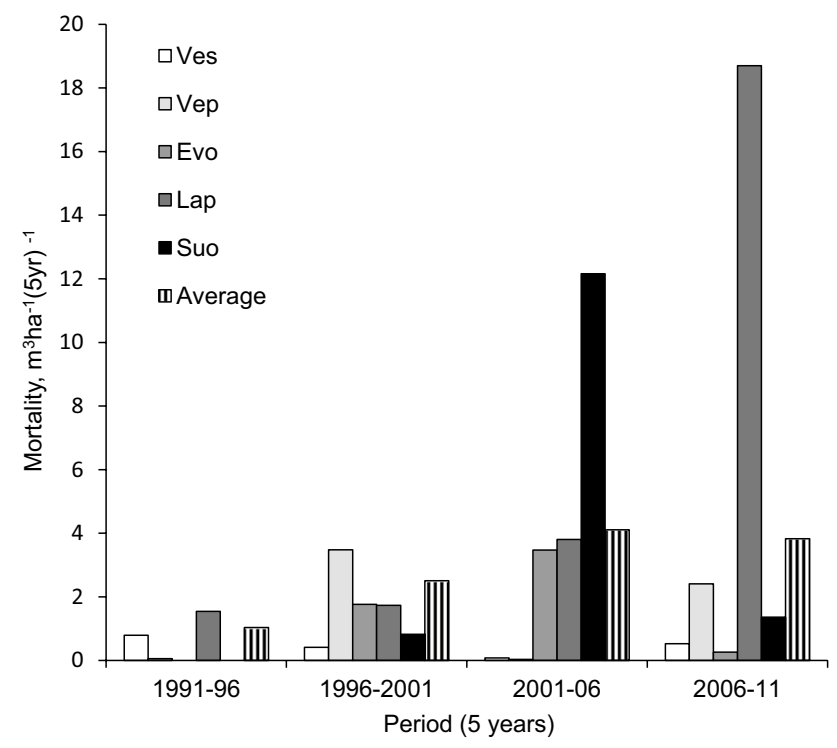

Fig. 1 The average mortality in terms of volume for subsequent 5 -year periods and locations, $\mathrm{m}^{3} \mathrm{ha}^{-1}(5 \mathrm{yr})^{-1}$ 


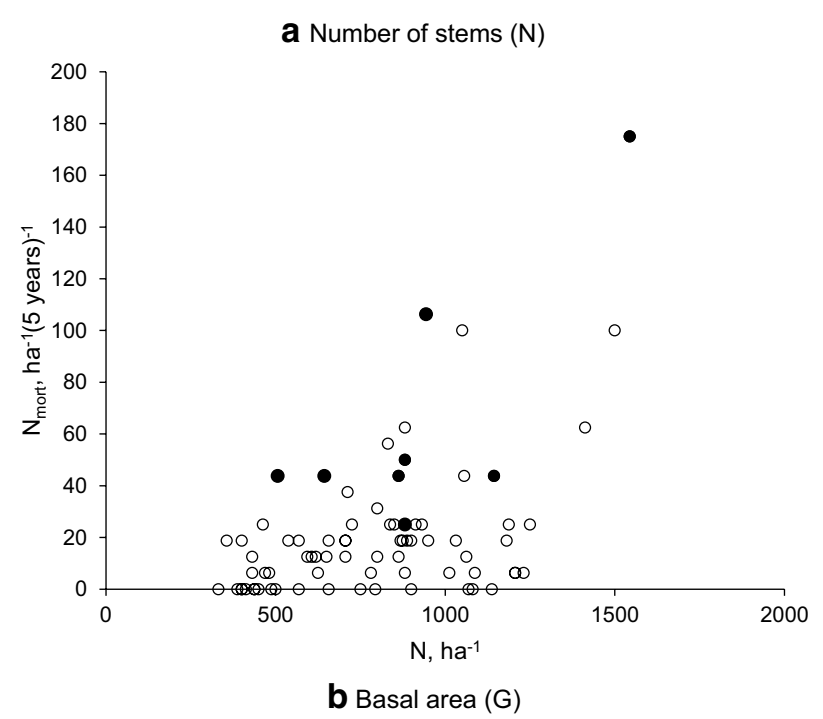

\section{Mortality and tree size}

Relatively more individuals died in the small diameter classes (Table 3). The average diameter of the dead trees was $11.8 \mathrm{~cm}$, while the stand average varied from 7.4 to $20.4 \mathrm{~cm}$. Most (57\%) of the mortality among larger trees $(d>20 \mathrm{~cm})$ occurred during two instances with exceptionally high mortality due to storm and Ips damage.

Figure 3 demonstrates the role of mortality across the diameter classes from postharvest in 1996 until preharvest in 2011. The mortality within a diameter class refers to the total number of trees that died during one of the three 5-year intervals within a diameter class (according to the diameter at the time of death). The mortality was then juxtaposed with the net change within the diameter class during the whole 15 -year period ( $N_{\text {end }}-N_{\text {beginning }}$ ), which consists of ingrowth from smaller diameter classes or saplings, upgrowth to larger diameter classes, mortality among trees that were present at the beginning, mortality among ingrown trees, and harvesting. The number of stems showed a net gain even at the smallest diameters despite substantial mortality (Fig. 3). The mortality was quite inconsequential in the larger diameter classes.

\section{Causes of mortality}

Of tree deaths by $N, 11 \%$ were assigned to wind and $16 \%$ to snow, $6 \%$ to intertree competition, and $7 \%$ to harvesting by the number of stems. In 55\% of cases the cause of tree death could not be identified; the field crew did not enter a cause if it was not quite obvious. For instance, tree deaths associated with the Ips outbreak at Lapinjärvi in 2011 that had killed a number of the largest trees in stand LAP 13 were entered as "unknown" in the field.

A minor part of the mortality was attributed to the one and only harvesting entry of the 20-year period in the winter of 1996/1997 with substantial uncertainty in the data for the small trees (see the Materials and methods section). Based on the trees that were assigned to harvest loss with a high degree of confidence, the average harvesting loss for the entry amounted to 8.3 trees $\mathrm{ha}^{-1}, 0.09 \mathrm{~m}^{2} \mathrm{ha}^{-1}$, and $0.58 \mathrm{~m}^{3}$ $\mathrm{ha}^{-1}$ in the 15 stands that were harvested. This constituted $7.5 \%$ of the $N$ value, $5.4 \%$ of the $G$ value and $4.3 \%$ of the $V$ value of the total mortality during the 20 -year period in the harvested stands.

\section{Discussion}

Fig. 2 a-c The stand density and mortality in terms of the stem number $(N)$, basal area $(G)$ and volume $(V)$ and the respective mortalities $\left(N_{\text {mort }}, G_{\text {mort }}, V_{\text {mort }}\right)$ for the subsequent 5-year period. The filled markers are for sites SUO in 2001-2006 and LAP in 2006-2011 with exceptionally high wind and Ips damage

The average annual mortality constituted a major proportion of the gross volume yield in the stands and reduced the net productivity in a respective proportion. During the 15-20 year observation period, the gross volume increment 
Table 2 A and B. Models for mortality by stand density variables: estimates and standard errors of parameters $a$ and $b$, square roots of estimated between-region and between-stand variances $\sigma_{w}^{2}$ and $\sigma_{z}^{2}$, estimates of precision parameter $\phi$, and $p$-values of the $F$-test of significant difference of $b$ from 0

\begin{tabular}{|c|c|c|c|c|c|c|c|c|c|}
\hline$Y$ & $X$ & $a$ & $\operatorname{se}(a)$ & $b$ & $\operatorname{se}(b)$ & $\sigma_{w}$ & $\sigma_{z}$ & $\phi$ & $p$ \\
\hline \multicolumn{10}{|c|}{ A. With the whole data } \\
\hline$N$ & $G$ & -3.7890 & 0.4089 & 0.0106 & 0.0196 & 0.1682 & $<0.00005$ & 51.3 & 0.5900 \\
\hline$G$ & $G$ & -4.6750 & 0.4934 & 0.0275 & 0.0226 & 0.3056 & $<0.00005$ & 39.1 & 0.2228 \\
\hline$V$ & $G$ & -4.7121 & 0.5203 & 0.0204 & 0.0238 & 0.3080 & $<0.00005$ & 33.8 & 0.3904 \\
\hline$N$ & $N$ & -3.8215 & 0.5999 & 0.0003 & 0.0007 & 0.1864 & $<0.00005$ & 52.3 & 0.6800 \\
\hline$V$ & $V$ & -4.3923 & 0.4418 & 0.0004 & 0.0020 & 0.3282 & $<0.00005$ & 33.6 & 0.8282 \\
\hline \multicolumn{10}{|c|}{$\begin{array}{l}\text { B. With 2001-2006 observations from site SUO and } \\
\text { 2006-2011 observations from site LAP excluded due to } \\
\text { exceptionally high wind and Ips damages. }\end{array}$} \\
\hline$N$ & $G$ & -3.6460 & 0.4206 & -0.0084 & 0.0214 & $<0.00005$ & $<0.00005$ & 67.8 & 0.6953 \\
\hline$G$ & $G$ & -4.9444 & 0.5172 & 0.0126 & 0.0250 & 0.1606 & $<0.00005$ & 80.0 & 0.6142 \\
\hline$V$ & $G$ & -5.1463 & 0.5507 & 0.0077 & 0.0265 & 0.1817 & $<0.00005$ & 77.5 & 0.7712 \\
\hline$N$ & $N$ & -3.8415 & 0.2335 & 0.0000 & 0.0003 & $<0.00005$ & $<0.00005$ & 67.7 & 0.8616 \\
\hline$V$ & $V$ & -4.8187 & 0.4698 & -0.0010 & 0.0024 & 0.2136 & $<0.00005$ & 78.4 & 0.6793 \\
\hline
\end{tabular}

The general model form is given in Eqs. (1)-(3)

$Y=$ dependent mortality variable, $X=$ independent stand density variable, $N=$ Number of stems, ha $^{-1,} G={\text { Basal area, } \mathrm{m}^{2} \text { ha }}^{-1,} V=$ Stemwood volume, $\mathrm{m}^{3} \mathrm{ha}^{-1}$

Table 3 Proportion of the number of stems in diameter classes at the beginning and at the end of the observation period, and relative average mortality ( $\%$ of $\left.N(5 \text { years })^{-1}\right)$ during the observation period, respectively

\begin{tabular}{llll}
\hline Diameter class, $\mathrm{cm}$ & \multicolumn{2}{l}{ Proportion (\%) } & Mortality (\%) \\
\cline { 2 - 3 } & Beginning & End & \\
\hline $5.01-10.00$ & 34 & 35 & 4.40 \\
$10.01-20.00$ & 34 & 31 & 2.15 \\
$20.01-30.00$ & 25 & 19 & 1.70 \\
$30.01-40.00$ & 6 & 11 & 0.75 \\
$40.01-$ & 1 & 3 & 1.30 \\
\hline
\end{tabular}

was $6.55 \mathrm{~m}^{3} \mathrm{ha}^{-1} \mathrm{a}^{-1}$, of which the mortality rate of $0.56 \mathrm{~m}^{3}$ $\mathrm{ha}^{-1} \mathrm{a}^{-1}$ constituted $8.4 \%$.

Lundqvist et al. (2007) reported stand-level mortality rates in two experimental stands treated with thinning from below or from above with variable intensities for a 10-year postharvest period. The "thinning from above" treatment at the southern site (Östersund) was relevant to our material, but the site represented less favorable conditions, especially due to its greater altitude $(485 \mathrm{~m})$. There the average annual mortality of trees with $d \geq 5 \mathrm{~cm}$ was $12 \mathrm{ha}^{-1} \mathrm{a}^{-1}$, which was almost three times as much as in our data.

For a set of Swedish permanent field trials managed with single-tree selection and observed for many decades with repeated measurements, the mortality for trees with $d>8.5 \mathrm{~cm}$ averaged 1.4 trees $\mathrm{ha}^{-1} \mathrm{a}^{-1}$. Mortality occurred throughout the diameter distribution, decreasing as the

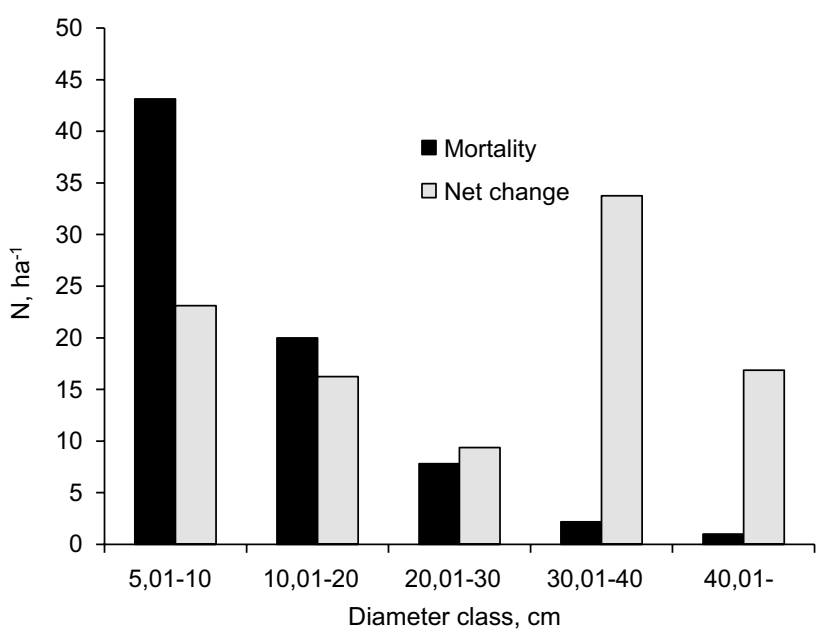

Fig. 3 The average net change and mortality in the number of stems $(N)$ across diameter classes throughout the 15-year period from the postharvest in 1996 until the preharvest 2011

diameter increased (Lundqvist 1993). The mortality rate observed in our data was about three times as high with a diameter range extending down to $5 \mathrm{~cm}$. Since trees $5-8.5 \mathrm{~cm}$ in diameter represented some $40 \%$ of the mortality in our data, we estimate that the mortality in our data was about twice as high as in the study by Lundqvist (1993).

Shanin et al. (2016) applied the process-based EFIMOD simulation system to data from the ERIKA plots.The mechanistic default procedure was used to estimate the mortality. The average annual mortality in volume was $0.63-1.89 \mathrm{~m}^{3}$ 
$\mathrm{ha}^{-1} \mathrm{a}^{-1}$, which was clearly higher than in our results. The models by Bollandsås et al. (2018), utilized for simulation by Rämö and Tahvonen (2014, 2015, 2017), Tahvonen and Rämö (2016), and Sinha et al. (2017) seem to yield mortality rates in $N$ that are level with our results. Applied to our data, the annual mortality rate of $N$ is around $0.9 \%$ with $d=5 \mathrm{~cm}$, declining to around $0.15 \%$ with $d=40 \mathrm{~cm}$. The models by Pukkala et al. $(2009,2013)$ and Tahvonen et al. (2010) give much lower mortality rates. Comparison with models from other areas was not considered justified.

Most of the mortality occurred in the smallest diameter classes. The mortality was about twice as large as the net increase in the number of stems during in the smallest diameter class $(5-10 \mathrm{~cm})$. Mortality was also relatively high in the next largest diameter class $(10-20 \mathrm{~cm})$, but some trees were also harvested and the point of comparison was not the same. In the larger diameter classes, harvesting was overwhelmingly dominant in controlling the net change, and the mortality was quite small in comparison. Mortality rates are higher yet among seedlings and saplings. Eerikäinen et al. (2014) reported an average annual mortality rate of 3.4\% for spruces which were $0.1-4 \mathrm{~m}$ in height, which is about four times as high as observed in the smallest diameter class $(5-10 \mathrm{~cm})$ in this study $(0.88 \%)$. The mortality rate for small trees may play a major role in controlling stand dynamics and the sustainability of preferable stand structures under such conditions.

Contrary to expectations, a relationship between stand density and mortality was not established with the mixed logistic beta regression models involving only the density and respective mortality variables. Consequently, our results do not endorse the recommendation that selection stands should be kept sparse by repeated heavy cuttings in order to ensure structural sustainability (Äijälä et al. 2019; Valkonen 2017).

Based on a systematic analysis of empirical mortality models in Europe, Hülsman (2016) concluded that the size of a tree, its growth, and competition are the most powerful predictors of tree death. Mortality among small trees was greater than among large ones, and slow growth and high stand density were linked to higher mortality. However, none of the models had been constructed specifically for unevenaged stands.

The type of mortality that can be covered with the experimental approach is restricted to mortality caused by consistent stand-level factors such as competition and harvesting, and random tree-level factors. Exceptional or rarely occurring high-severity events resulting in stand-replacing disturbances, often with landscape-level or even more extensive characteristics, cannot be captured with stand-level experimental designs. The differentiation between these event types is not quite distinct of course (Weiskittel et al. 2011; Hülsman 2016). In this case, there were two instances with above-average mortality during a specific period, at a specific location, and due to a specific cause that could be considered exceptional. First, relatively heavy storm damage that occurred at the Suonenjoki site in three stands out of four in 2002. We consider this a semi-regular event in this context. The storm was strong enough to fell a considerable number of trees, but nothing out of the ordinary in terms of wind force or geographic extent, or consequences to stand structures and dynamics. Second, there was a severe Ips typographus outbreak at the Lapinjärvi site in 2011, where it killed a substantial number of large spruces. The event was part of an Ips epidemic in Southeastern Finland with a severity and geographic extent not seen for decades in Finland. The cumulative effect of the exposure to heat and severe drought during several warm summers that triggered the outbreak (Kukkonen 2013). It is noteworthy that most of the mortality among larger trees $(d>20 \mathrm{~cm})$ in the data occurred during these two instances.

The observation period of 15-20 years contained only one harvesting entry, while the recommended interval under such circumstances would be around 15 years. If we correct the harvest loss level in the results by a factor of 1.33 , the harvest loss would thus average 0.5 trees $\mathrm{ha}^{-1} \mathrm{a}^{-1}$ in $N$ and $0.04 \mathrm{~m}^{3} \mathrm{ha}^{-1} \mathrm{a}^{-1}$ in $V$, representing $10 \%$ and $6 \%$ of the total mortality with an emphasis on the smaller trees Harvesting losses were probably less common in the experimental setting than could be expected in practical harvesting under similar conditions. The study by Sirén et al. (2015) was conducted under comparable conditions on practical harvesting sites. In a single entry, the proportion of fatally damaged trees was $5.8 \%$ of $N$, while in this study it was somewhere around $1-2 \%$. However, our data lacked the very smallest trees $(0.1-5 \mathrm{~cm})$ included in their study, which are particularly vulnerable to damage in harvesting (Surakka et al. 2011). In the study by Modig et al. (2012) under comparable conditions, the overall damage level was $4.5 \%$ (of $N)$. Over $80 \%$ of the damaged trees belonged to the smallest diameter class $(d 8-15 \mathrm{~cm})$.

Wind was the most common cause of mortality in terms of volume. The amount of wind damage was actually very low, if the local incident at Suonenjoki in 2002 that felled many large trees is considered exceptional. Otherwise, only individual trees were felled in strong winds or weaker storms. Pukkala et al. (2016) reported that in an experimental setting with variable even-aged and uneven-aged management regimes that uneven-sized, multilayered stand structures (dimension harvesting and high selective thinning) were associated with a very low probability of wind throw compared with low thinning and shelterwood cutting in the even-aged management context. According to Mason (2002), irregular stands may provide structures with more stable characteristics, but these cannot be considered in isolation from the prevailing wind climate and the local 
site type. Nevalainen (2017) pointed out that the level of wind damage risk depends greatly on forest management, and damage is most probable in stands adjacent to newly clearcut areas or in stands that have recently been heavily thinned (Valinger and Pettersson 1996; Gardiner et al. 1997; Peltola et al. 1999; Suvanto et al. 2016; Suvanto 2018). In our study, a substantial proportion of tree deaths was also attributed to snow damage in terms of number of stems but not in volume, as only small stems were affected.

In our study data, the almost complete absence of biotic causes (mammals, insects, pathogens) is noteworthy, except for the Ips outbreak that killed several large trees at the Lapinjärvi site. Biotic damage is very common and often serious in even-aged management in Finnish forests (Nevalainen et al. 2015; Nevalainen 2017). The greatest single deterrent in uneven-aged stands is probably the lack of suitable and susceptible host material (Nevalainen 2017). Pathogens, particularly fungi which cause root rot, were completely absent from the list of identified causes of tree death. A serious root rot infection was known to be present in the stands in Lapinjärvi during the study period. A survey targeting decayed stumps of the trees removed in harvesting in the winter of 2011-2012 was carried out to determine the causal agents. It revealed that on average $42 \%$ of decay was caused by Heterobasidion parviporum (Niemelä and Korhonen). At the other sites, only sporadic infections were detected, and the average proportion of Heterobasidion of decays in harvest stumps was $1.9 \%$, (a range of $0-7 \%$ between stands). The second most common decay fungus was Armillaria sp. (ca. 17\%) (senior researcher Tuula Piri, Natural Resources Institute Finland [Luke], personal communication). The role of root rot in the tree mortality remained unclear as it is very difficult to determine whether an infected tree was killed by the fungus or just weakened and died of another cause.

One of the major areas of dispute concerning unevenaged management approaches in the Nordic context is the productivity, mainly volume yield, compared to the predominant even-aged management approaches used (cf. Lundqvist 2017), in which different mortality rates could be important. Direct experimental comparisons of mortality in single-tree selection and even-aged management are not available. The thinning experiments used by Hynynen et al. (2019) for comparing volume yields under even- and uneven-aged management may serve as the most relevant reference here, too. The experimental set contains Norway spruce stands with variable intensities of thinning from below in 21 middle-aged stands in Southern Finland. Mäkinen and Isomäki (2004) reported that the average mortality in volume was $0.82 \mathrm{~m}^{3} \mathrm{ha}^{-1} \mathrm{a}^{-1}$ for an observation period covering an average of 27 years. The mortality was thus somewhat higher than in the selection stands of this study which were $0.56 \mathrm{~m}^{3} \mathrm{ha}^{-1} \mathrm{a}^{-1}$. The obvious uncertainties of such an indirect comparison are too large to justify definitive conclusions to be drawn.

The average mortality $\left(0.56 \mathrm{~m}^{3} \mathrm{ha}^{-1} \mathrm{a}^{-1}\right)$ was six times higher compared with the prediction $\left(0.08 \mathrm{~m}^{3} \mathrm{ha}^{-1} \mathrm{a}^{-1}\right)$ of the MOTTI system for a rotation of even-aged planted spruce on similar sites, managed according to best practices (Äijälä et al. 2019). However, such a direct comparison is not justified. The natural mortality models in MOTTI account only for the mortality related to within-stand competition in the absence of disturbances. This ignores the risks of extensive abiotic and biotic damages caused by wind, snow, fire, pathogens or insects and harvesting losses (Hynynen et al. 2002, 2014). Random or semi-random events like the heavy windthrow at Suonenjoki and the Ips outbreak at Lapinjärvi and harvesting losses are intentionally excluded in the MOTTI predictions for regular stand development, and so are harvesting losses, too. In that case the comparable rate in this study would have been $0.20 \mathrm{~m}^{3} \mathrm{ha}^{-1} \mathrm{a}$. . This is less than Elfving (2006) calculated for optimal management regimes for Swedish spruce forests with the Heureka simulation system. The alternative representing typical regimes in evenaged management with the highest site index $\left(H_{100}=30 \mathrm{~m}\right)$ was a relevant point of comparison here. During the respective rotation of 70 years the average annual mortality was $0.61 \mathrm{~m}^{3} \mathrm{ha}^{-1} \mathrm{a}^{-1}$, which excluded mortality caused by harvesting which consisted of two thinnings.

Uneven-aged management is widely applied in European forests where Norway spruce has a dominant or co-dominant position. The novel results and conclusions of this study are applicable in Norway spruce-dominated selection stands in the southern boreal zone (Ahti et al. 1968) of central Fennoscandia, but they may also have relevance under comparable conditions elsewhere (e.g., hemiboreal and boreal lowland forests, as well as montane and subalpine spruce forests).

\section{Conclusions}

The results confirmed that mortality is an important dynamic component of stand structure and productivity in spruce-dominated stands managed using a single-tree selection approach and must be taken into account in research and management. Natural mortality and harvesting losses can significantly reduce the pool of smaller trees in selection stands if not resolutely contained, making it more difficult to maintain a favorable selection structure in the long run. It is very important to try to minimize the mortality of saplings and small trees in management, particularly harvesting. In the larger diameter classes, regular mortality is low and the dynamics are overwhelmingly dominated by harvesting. Random or semi-random events, 
such as a storm and an Ips epidemic in this case, may play a role and must be taken into account in the planning and execution of treatments.

Acknowledgements Open access funding provided by Natural Resources Institute Finland (LUKE). This study was conducted at the Natural Resources Institute Finland (Luke), utilizing data from the ERIKA permanent experiment. We are grateful to Hilkka Ollikainen and Juhani Korhonen, who mastered the maintenance and measurements on the plots throughout the long monitoring period, producing a data set of excellent quality that made this study possible.

Author contributions All authors contributed to the study conception and design, and analysis. The material preparation and data collection were performed by Sauli Valkonen and Lucie Aulus Giacosa. All authors contributed to the first draft of the manuscript and commented on previous versions of the manuscript. All authors read and approved the final manuscript.

Funding This study was conducted at and exclusively funded by the Natural Resources Institute Finland (Luke).

\section{Compliance with ethical standards}

Conflict of interests The authors declare that they have no conflict of interests.

Availability of data and material The datasets generated and analyzed during the current study are available from the corresponding author on reasonable request.

Code availability Not applicable.

Open Access This article is licensed under a Creative Commons Attribution 4.0 International License, which permits use, sharing, adaptation, distribution and reproduction in any medium or format, as long as you give appropriate credit to the original author(s) and the source, provide a link to the Creative Commons licence, and indicate if changes were made. The images or other third party material in this article are included in the article's Creative Commons licence, unless indicated otherwise in a credit line to the material. If material is not included in the article's Creative Commons licence and your intended use is not permitted by statutory regulation or exceeds the permitted use, you will need to obtain permission directly from the copyright holder. To view a copy of this licence, visit http://creativecommons.org/licenses/by/4.0/.

\section{References}

Ahlström M, Lundqvist L (2015) Stand development during $16-57$ years in partially harvested sub-alpine uneven-aged Norway spruce stands reconstructed from increment cores. For Ecol Manag 350:81-86

Ahti T, Hämet-Ahti L, Jalas J (1968) Vegetation zones and their sections in northwestern Europe. Ann Botan Fenn 5:169-211

Bircher N (2015) To die or not to die: Forest dynamics in Switzerland under climate change. ETH Zürich, Dissertation No. 22775. 188 p. https://doi.org/10.3929/ethz-a-010596194

Björkman C, Bylund H, Klapwijk MJ, Kollberg I, Schroeder M (2011) Insect pests in future forests: More severe problems? Forests 2:474-485
Bollandsås O, Buongiorno J, Gobakken T (2018) Predicting the growth of stands of trees of mixed species and size: a matrix model for Norway. Scand J For Res 23:167-178

Brooks ME, Kristensen K, van Benthem KJ, Magnusson A, Berg CW, Nielsen A, Skaug HJ, Maechler M, Bolker BM (2017) glmmTMB balances speed and flexibility among packages for zero-inflated generalized linear mixed modeling. The R J 9:378-400

Buongiorno J, Halvorsen E, Bollandsås $\mathrm{O}$, Gobakken T, Hofstad O (2012) Optimizing management regimes for carbon storage and other benefits in uneven-aged stands dominated by Norway spruce, with a derivation of the economic supply of carbon storage. Scand J For Res 27:460-473

Cajander A (1926) The theory of forest types. Acta For Fenn 29(3): $1-108$

Cordonnier T, Courbaud B, Berger F, Franc A (2008) Permanence of resilience and protection efficiency in mountain Norway spruce forest stands: a simulation study. For Ecol Manag 256:347-354

Eerikäinen K, Valkonen S, Saksa T (2014) Ingrowth, survival and height growth of small trees in uneven-aged Picea abies stands in southern Finland. For Ecosys 1(5):1-10. https://doi. org/10.1186/2197-5620-1-5

Eid T, Tuhus E (2001) Models for individual tree mortality in Norway. For Ecol Manag 154:69-84

Elfving B (2006) Produktion vid byte från trakthyggen till blädning [Prodcution with transformation from even-aged to unevenaged management]. Redogörelse från Skogforsk 5/2006: 12-23. Swedish

Ferrari S, Cribari-Neto F (2004) Beta regression for modelling rates and proportions. J Appl Stat 31:799-815

Fjeld D, Granhus A (1998) Injuries after selection harvesting in multistoried spruce stands-the influence of operating systems and harvest intensity. J For Eng 9:33-40

Gardiner B, Stacey G, Belcher R, Wood C (1997) Field and wind tunnel assessments of the implications of respacing and thinning for tree stability. Forestry 70:233-252

Gobakken T, Lexeröd N, Eid T (2008) T: a forest simulator for bioeconomic analyses based on models for individual trees. Scand $\mathrm{J}$ For Res 23:250-265

Granhus A, Fjeld D (2001) Spatial distribution of injuries to Norway spruce advance growth after selection harvesting. Can J For Res 31:903-913

Hilmers T, Biber P, Knoke T, Pretzsch H (2020) Assessing transformation scenarios from pure Norway spruce to mixed uneven-aged forests in mountain areas. Eur J For Res. https://doi.org/10.1007/ s10342-020-01270-y

Hülsman L (2016) Tree mortality in Central Europe: Empirically-based modeling using long-term datasets. ETH Zürich, Dissertation No. 23782. 217 p. https://doi.org/10.3929/ethz-a-010881810

Hynynen J, Ojansuu R, Hökkä H, Siipilehto J, Salminen O, Haapala P (2002) Models for predicting stand development in MELA system. Metsäntutkimuslaitoksen tied 835:1-116

Hynynen J, Salminen H, Ahtikoski A, Huuskonen S, Ojansuu R, Siipilehto J, Lehtonen M, Rummukainen A, Kojola S, Eerikäinen K (2014) Scenario analysis for the biomass supply potential and the future development of Finnish forest resources. Work Pap Finn For Res Inst 302: 1-103. http://www.metla.fi/julkaisut/worki ngpapers/2014/mwp302.htm

Hynynen J, Eerikäinen K, Mäkinen H, Valkonen S (2019) Growth response to cuttings in Norway spruce stands under even-aged and uneven-aged management. For Ecol Manag 437:314-323

Klapwijk M, Bylund H, Schroeder M, Björkman C (2016) Forest management and natural biocontrol of insect pests. Forestry $89: 253-262$

Kukkonen H (2013). Kirjanpainaja-kaarnakuoriaisen tuhot Metsänhoitoyhdistys Uusimaan alueella vuosina 2010-2011. [European spruce bark beetle damage in the area of the Häme-Uusimaa 
Metsänhoitoyhdistys]. Thesis. Karelia-ammattikorkeakoulu, Metsätalouden koulutusohjelma, Joensuu: 1-36. http://urn.fi/ URN:NBN:fi:amk-201302222498. Finnish

Laasasenaho J (1982) Taper curve and volume functiuns for pine, spruce and birch. Comm Inst For Fenn 108:1-74

Lundqvist L (1993) Changes in the stand structure on permanent Picea abies plots managed with single tree selection. Scand J For Res 8:510-517

Lundqvist L (2004) Stand development in uneven-aged sub-alpine Picea abies stands after partial harvest estimated from repeated surveys. Forestry 77:119-129

Lundqvist L (2017) Tamm review: selection system reduces long-term volume growth in Fennoscandic uneven-aged Norway spruce forests. For Ecol Manag 391:362-375

Lundqvist L, Chrimes D, Elfving B, Mörling T, Valinger E (2007) Stand development after different thinnings in two uneven-aged Picea abies forests in Sweden. For Ecol Manag 238:141-146

Mäkinen H, Isomäki A (2004) Thinning intensity and growth of Norway spruce stands in Finland. Forestry 77(4):349-364

Mason W (2002) Are irregular stands more windfirm? Forestry $75: 347-355$

Mayer H (1999) Waldbau auf soziologisch-ökologischer Grundlage [Silviculture with a socio-ecological basis]. 4., neu bearbeitete Auflage. Gustav Ficher Verlag, Stuttgart. ISBN 978-3437306846

Modig E, Magnusson B, Valinger E, Cedergren J, Lundqvist L (2012) Damage to residual stand caused by mechanized selection harvest in uneven-aged Picea abies dominated stands. Silva Fenn. https:// doi.org/10.14214/sf.442

Nevalainen S (2017) Comparison of damage risks in even- and uneven-aged forestry in Finland. Silva Fenn 51(3):1-28. https://doi. org/10.14214/sf.1741

Nevalainen S, Ihalainen A, Korhonen KT (2015) Metsätuhojen esiintyminen 11. VMI:n koealoilla vuosina 2009-2013 [Forest disease and damage on the sample plots of the 11th National Forest Inventory in 2009-2013]. In: Heino E, Pouttu, A (eds) Metsätuhot vuonna 2014 [Forest disease and damage in 2014]. Luonnonvaraja biotalouden tutkimus 39/2015: 7-10. Finnish

O'Hara K, Ramage B (2013) Silviculture in an uncertain world: utilizing multi-aged management systems to integrate disturbance. Forestry 86:401-410

Peltola H, Kellomäki S, Väisänen H, Ikonen VP (1999) A mechanistic model for assessing the risk of wind and snow damage to single trees and stands of Scots pine, Norway spruce, and birch. Can J For Res 29:647-661

Pukkala T, Lähde E, Laiho O (2009) Growth and yield models for uneven-sized forest stands in Finland. For Ecol Manag 258:207-216

Pukkala T, Lähde E, Laiho O (2013) Species interactions in the dynamics of even- and uneven-aged boreal forests. J Sust For 32:371-403

Pukkala T, Laiho O, Lähde E (2016) Continuous cover management reduces wind damage. For Ecol Manag 372:120-127

R Core Team (2019) R: A language and environment for statistical computing. R Foundation for Statistical Computing, Vienna, Austria. URL https://www.R-project.org/. [Accessed May 10, 2019]

Rämö J, Tahvonen O (2014) Economics of harvesting uneven-aged forest stands in Fennoscandia. Scand J For Res 29:777-792

Rämö J, Tahvonen O (2015) Economics of harvesting boreal unevenaged mixed-species forests. Can J For Res 45:1102-1112
Rämö J, Tahvonen O (2017) Optimizing the harvest timing in continuous cover forestry. Environ Resour Econ 67:853-868

Saksa T (2004) Regeneration process from seed crop to saplings-a case study in uneven-aged Norway spruce-dominated stands in southern Finland. Silva Fenn 38(4):371-381

Saksa T, Valkonen S (2011) Dynamics of seedling establishment and survival in uneven-aged boreal forests. For Ecol Manag 261(8):1409-1414

Schütz JP (2001) Der Plenterwald und weitere Formen strukturierter und gemischter Wälder [Single-tree selection and other forms of silviculture with structurally complex and mixed-species forests]. Parey, Berlin. ISBN 3-8263-3347-0

Shanin V, Valkonen S, Grabarnik P, Mäkipää R (2016) Using forest ecosystem simulation model EFIMOD in planning uneven-aged forest management. For Ecol Manag 378:193-205

Sinha A, Rämö J, Malo P, Kallio M, Tahvonen O (2017) Optimal management of naturally regenerating uneven-aged forests. Eur J Oper Res 256:886-900

Sirén M, Hyvönen J, Surakka H (2015) Tree damage in mechanized uneven-aged selection cuttings. Croat J For Eng 36:33-42

Surakka H, Sirén M, Heikkinen J, Valkonen S (2011) Damage to saplings in mechanized selection cutting in uneven-aged Norway spruce stands. Scand J For Res 26:232-244

Suvanto S (2018) Drivers of annual variation in tree growth and forest sensitivity to storm damage in Finland. Dissertation. University of Helsinki, Department of Geosciences and Geography, A62: 1-39

Suvanto S, Henttonen H, Nöjd P, Mäkinen H (2016) Forest susceptibility to storm damage is affected by similar factors regardless of storm type: comparison of thunder storms and autumn extratropical cyclones in Finland. For Ecol Manag 381:17-28

Tahvonen O, Rämö J (2016) Optimality of continuous cover vs. clear-cut regimes in managing forest resources. Can J For Res 46:891-901

Tahvonen O, Pukkala T, Laiho O, Lähde E, Niinimäki S (2010) Optimal management of uneven-aged Norway spruce stands. For Ecol Manag 260:106-115

Väisänen P, Äijälä O, Koistinen A, Sved J, Vanhatalo K, Väisänen P (eds) (2019) Metsänhoidon suositukset. [Best practices for forest management]. Tapion julkaisuja, Helsinki

Valinger E, Pettersson N (1996) Wind and snow damage in a thinning and fertilization experiment in Picea abies in southern Sweden. Forestry 69:25-34

Valkonen S (2017) Metsän jatkuvasta kasvatuksesta [Forest management with selection systems]. Natural Resources Institute Finland (Luke). Metsäkustannus, Helsinki, pp 1-124. ISBN 978-952-238-003-5

Weiskittel A, Hann D, Kershaw J, Vanclay J (2011) Forest growth and yield modeling. 2nd edition. Wiley-Blackwell, Chicester, UK. pp 139-155. ISBN 9780470665008.

Publisher's Note Springer Nature remains neutral with regard to jurisdictional claims in published maps and institutional affiliations. 